\title{
Operation of Battery Energy Storage System in Demand Side using Local Load Forecasting
}

\author{
Yusuke Hida Student Member (Waseda University, yusuke.h@akane.waseda.jp) \\ Ryuichi Yokoyama Senior Member (Waseda University) \\ Jun Shimizukawa Student Member (Meisei University) \\ Kenji Iba Senior Member (Meisei University) \\ Kouji Tanaka Member (Tokyo Electric Power Company) \\ Tomomichi Seki Member (Tokyo Electric Power Company)
}

Keywords: BESS, NAS battery, load leveling, load forecasting, multi-regression model, load following operation

Recently, battery energy storage system (BESS) attracts attention as measures for reducing $\mathrm{CO} 2$-emission and has been widely used all over the world. NAS (sodium and sulfur) battery is a relatively new large-capacity product in BESS and has been used at 215 sites (total $302 \mathrm{MW}$ ) in the world in 2009. NAS battery systems have been installed in demand side in Japan. Meisei University has installed and operated NAS battery of $1000 \mathrm{~kW}$ at campus since July in 2003. The recorded data shows its stable operation throughout more than six-years.

In this paper, the proposed operation of the load following is demonstrated base on the six-year's records of the load at Meisei University campus. Firstly, the load curves on demand side are forecasted using multi-regression model. The accuracy of this forecasting model is important to design the demand control. Four factors are selected as explanatory variables in the first stage. They are the weekly load, the day of week, the mean temperature and the present load. The load forecast and the control of battery are repeated at regular intervals in the forecasted day. The high accuracy load forecast can be simulated by repeating in the day, because many data can be obtained by passage of time.

Secondly, the load following control is simulated with the forecasted curves. In this simulation, the stability of the forecasting is examined from the error of the forecasted load in the past, and the reserve (margin) of battery energy is considered to prevent the shortage/surplus of battery energy. Figure 1 is shown the procedure of load following operation. $\mathrm{P}_{0}$, which is a target of receiving power from utility, is calculated to cut the peak part of the forecasted load curve. If the receiving power exceeds $\mathrm{P}_{0}$, NAS battery starts to discharge the amount of excess.
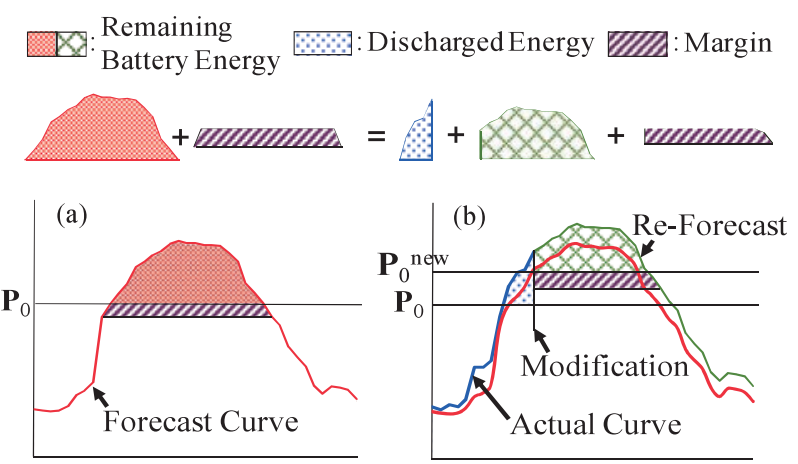

Fig. 1. Procedure of load following operation control
A proper amount of charged energy is classified as margin. The margin is not used until risks are over. The adequate amount of margin is specified from engineering judgment, taking account of statistical data of past performance.

The mean error of forecast is evaluated and some examples at 8:00/12:00 are shown in the histogram in Fig. 2. Although the mean errors at 8:00 often exceed 10\%, all mean errors at 12:00 stay within $7 \%$.

The numerical simulation was carried out against 151 school days in 2008. Figure 3 shows example of the load following operation simulation. The load leveling of receiving power is well achieved. NAS battery on Meisei University has been operated by a fixed pattern operation mode up to now. As the results, the maximum receiving power is successfully suppressed by proposed load following operation mode, rather than the fixed pattern operation mode. It is our future work to apply this control method to various types of loads to confirm the robustness of the proposed method.

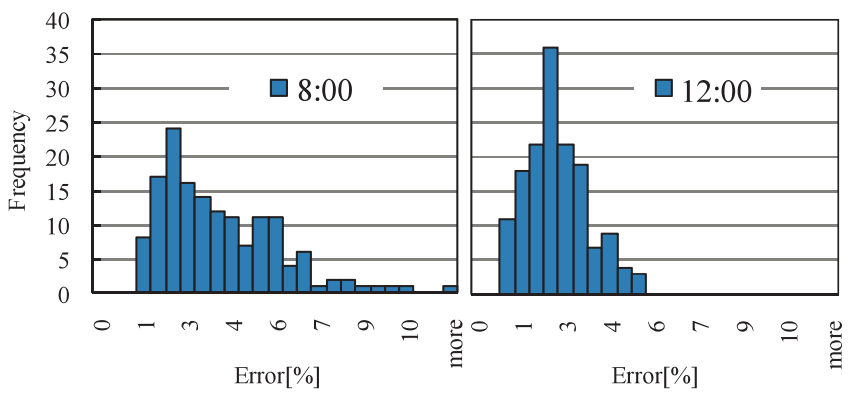

Fig. 2. Forecast error distribution histogram of 151 days

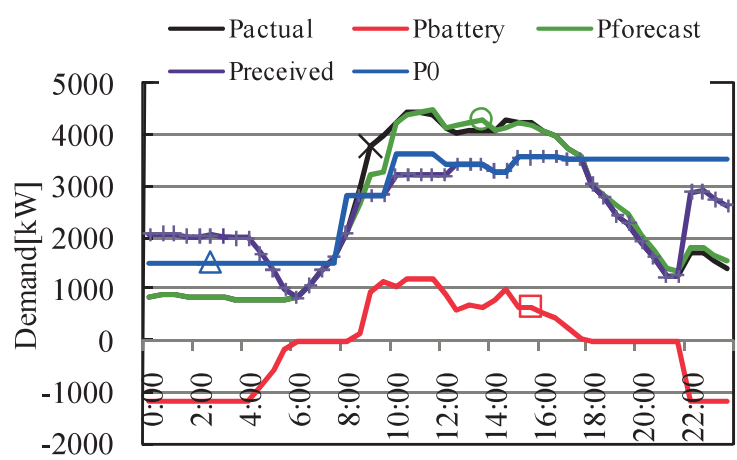

Fig. 3. Load levelling of the load following operation mode 


\title{
需要家における需要予測を用いた電力貯蔵用システムの運用制御
}

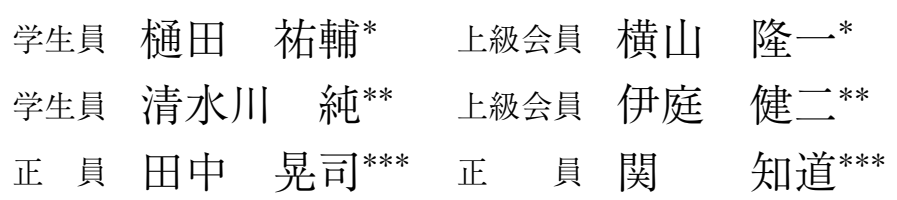

\section{Operation of Battery Energy Storage System in Demand Side using Local Load Forecasting}

\begin{abstract}
Yusuke Hida*, Student Member, Ryuichi Yokoyama*, Senior Member, Jun Shimizukawa**, Student Member,
\end{abstract} Kenji Iba**, Senior Member, Kouji Tanaka***, Member, Tomomichi Seki***, Member

Recently, the various political movements, which reduce $\mathrm{CO} 2$-emission, have been proposed against global warming. Therefore, battery energy storage systems (BESSs) such as NAS (sodium and sulfur) battery are attracting attention around the world. The first purpose of BESS was the improvement of load factors. The second purpose is the improvement of power quality, especially against voltage-sag. The recent interest is oriented to utilize BESS to mitigate the intermittency of renewable energy.

NAS battery has two operation modes. The first one is a fixed pattern operation, which is time-schedule in advance. The second mode is the load following operation. Although this mode can perform more the flexible operation by adjusting the change of load, it has the risks of shortage/surplus of battery energy. In this paper, an accurate demand forecasting method, which is based on multiple regression models, is proposed. Using this load forecasting, the more advanced control of load following operation for NAS battery is proposed.

キーワード : 電力貯蔵用蓄電池, NAS 電池, 負荷平準化, 需要予測, 重回帰分析, 負荷追従運転

Keywords: BESS, NAS battery, load leveling, load forecasting, multi-regression model, load following operation

\section{1. まえがき}

負荷平準化は電源設備の効率的な運用や発電コストの低 減に効果があり，国内でも揚水発電所の活用など負荷率の 向上が図られてきた。需要家に対しても，夏季の電気料金 単価の高いピーク帯に放電することで, 電気料金のメリッ トがある。

一方, 低炭素社会に向けた対策として, 風力発電・太陽 光発電といった再生可能エネルギーの導入が加速している

\footnotetext{
*早稲田大学大学院環境・エネルギー研究科

干 169-8555 東京都新宿区大久保 3-4-1 55S-705

Graduate School of Environment and Energy Engineering, Waseda University

55S-705 3-4-1, Okubo, Sinjuku-ku, Tokyo 169-8555

** 明星大学理工学部電気電子システム工学科

于 191-8506 日野市程久保 2-1-1 29-704

Department of Electrical and Electronic Engineering, Meisei University

29-704 2-1-1, Hodokubo, Hino 191-8506

*** 東京電力 (株)

₹ 100-8560＼cjkstart東京都千代田区内幸町 1-1-3

Tokyo Electric Power Company

1-1-3, Uchisaiwai-cho, Chiyoda-ku, Tokyo 100-8560
}

が, 風力・太陽光発電は天候により出力が大きく変動し不 確実なので，これを安定化することが重要な課題となる ${ }^{(1)} 。$ この出力変動の緩和策としても, NAS 電池のような電力貯 蔵装置の大量導入が一部の風力発電所で進められている。

NAS 電池はナトリウムと硫黄からなる二次化学電池であ り，放電時間が 7.2 時間と大容量であるのが特徴である。 実用化されている大容量の蓄電池による電力貯蔵システム (Battery Energy Storage System：BESS）としては最普及 しており，世界中で $270 \mathrm{MW} / 200$ 箇所が, 東京電力管内で も $180 \mathrm{MW} / 95$ 箇所が導入されている。明星大学では 2003 年 7 月から定格出力 $1000 \mathrm{~kW}$ の NAS 電池を運用し, 需要 と NAS 電池運用実績データを逐次蓄積している。Fig. 1 に は運用実績を, NAS 電池の外観と仕様を Fig. 2 と Table 1 に示す。運用実績から長期停止もなく安定して運用されて いることや, 年ごとに需要が増加し予測が容易でないこと がわかる。

本稿では需要家に設置された NAS 電池の運用制御に関 して,はじめに重回帰モデルを用いた需要予測手法を提案 する。電力の需要予測はこれまでも広く研究されてきたが, その多くは電力会社管内の需要予測であり, 需要家内等で の限られた地域での予測の事例は少ない。限られた地域で 


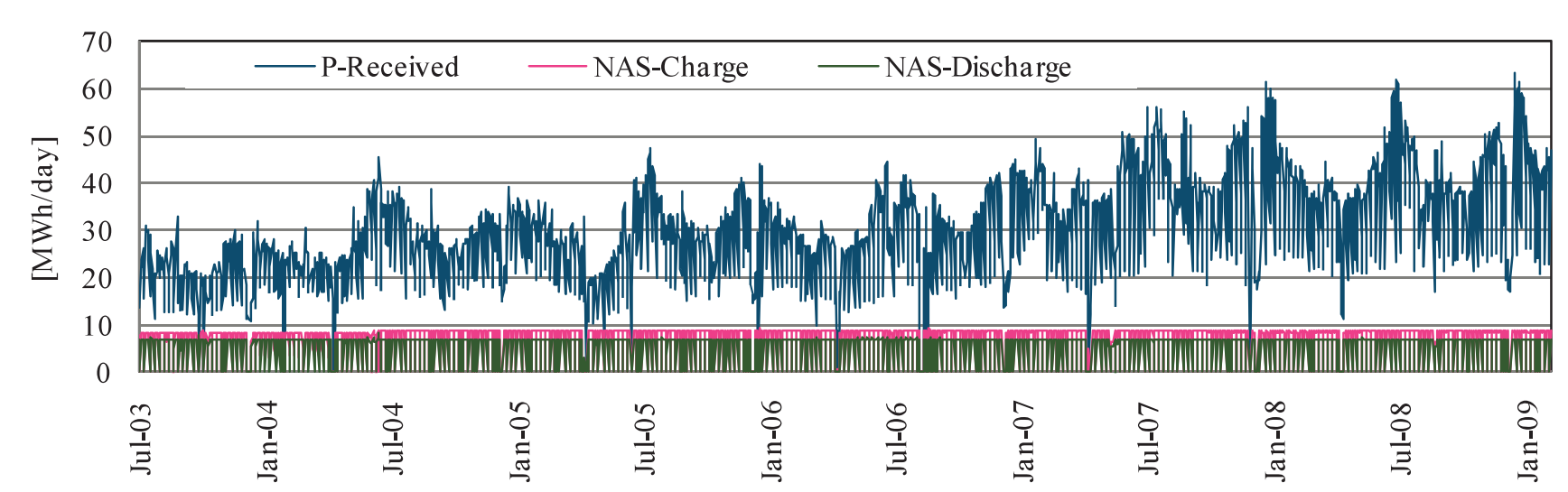

Fig. 1. Operation record of NAS battery in Meisei University (from 26 July 2003 to 3 Mar 2009).
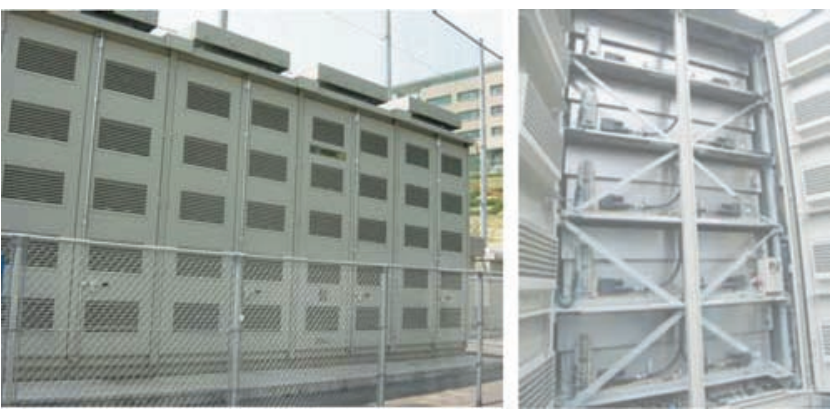

Fig. 2. Appearance of NAS battery in campus (Meisei University).

Table 1. Specification of NAS battery in Meisei University.

\begin{tabular}{|l|l|}
\hline Rated Output & $1000 \mathrm{~kW}$ \\
\hline Rated Voltage & $6.6 \mathrm{kV} \quad$ (Three phase $)$ \\
\hline Units & 4 Units $\quad(250 \mathrm{~kW} \times 4$ units $)$ \\
\hline Energy Storage & AC7200kWh \\
\hline Battery Module & $\begin{array}{l}5 \text { module per unit } \\
384 \text { battery cells per module }\end{array}$ \\
\hline
\end{tabular}

は，需要変動要因が限定されているが，その情報が簡便に 入手できないため需要予測が難しい。

次に考案した負荷追従運転の制御ロジックを紹介し，そ の有力性を明らかにする。ここでいう負荷追従制御は需要 変動に応じて目標受電電力（これを超過した分 NAS 電池 が放電する閾值）を変化させ, NAS 電池の出力を制御して 受電電力を平準化するもので, 契約料金に影響を与える最 大電力の抑制と電気料金の昼夜間差を最大限に利用するこ とを目的としている。

\section{2. 需要予測}

$\langle\mathbf{2} \cdot \mathbf{1}\rangle$ 従来の研究

これまで電力会社管内の翌日の 最大電力 (ピーク需要) や需要曲線を予測する研究が広く 行われて㧍り，AIを使うものや， ARIMA モデルのような 時系列解析を使うもの, 重回帰分析を使うものなどが提案 されてきた(2)(3)。これらは電力会社において翌日の発電機 の起動停止計画に用いられる重要な業務のひとつである。 需要家内の需要予測の必要性は少なかったが, マイクログ
リッドの実証試験等 (4)では単独運転に不可欠な技術となり 精度の高い予測手法が使われた。需要家内の需要は機器単 位まで捕捉できる場合もあるが，エネルギー管理者に事前 に需要予測に必要な情報が入らない場合も多く, 平均化の 効果が少ないだけ予測が難しいと言われている。

筆者らはこれまでの研究で, 明星大学日野キャンパスの 過去 5 年間の実績デー夕を用いて重回帰分析を行い翌日の 需要予測曲線を求める研究を続けてきた ${ }^{(5)}$ 。この過程で需 要家の需要予測に関して以下の知見を得た。

・実績デー夕に対して重回帰分析を行い, 需要と説明変 数に因果関倸があることがわかった。

- 説明変数の候補から多重共線性 (multi-co-linearity) の 疑いがあるものや, F值の小さい变数を除外して分析を 繰り返す変数減少法を用いて, 説明変数を確定できる。

・過去 5 年のデー夕蓄積があるが, 重回帰分析の対象に するのは過去 1 年のデータが適している。

・翌日の需要曲線予測を第 1 段階で開発したが, 負荷追 従制御には，制御当日の逐次予測が必要である。

本稿では, NAS 電池の負荷追従運転に必要な実時間の需 要予測を目標として開発した新たな予測手法を提案する。 この手法は以下の要求仕様に従って開発された。

・現制御時点から 22 時までの需要曲線を予測する。

・特異日や稀頻度事象にも例外処理無く予測ができる。

・通信やネットワークを使わず, 電池設置サイト内で完 結したシステム構成にする。

・年間を通して予測をし続け, デー夕の更新や年度の切 り替え作業を必要としないシームレスな構成にする。

$\langle\mathbf{2} \cdot \mathbf{2}\rangle$ 重回帰分析を用いる需要予測手法 需要に変 動を与える相関の強い要素を説明変数として用意する。変 数減少法を用いた結果，(1) 週，(2) 曜日，(3) 気温，(4) 予測対象日当日の需要実績, の 4 つの要素を説明変数とし て重回帰モデル式を構築する。(1) 式に重回帰モデル式を 示す。

$$
\begin{aligned}
& P_{i, j}=a_{1} x_{1}+a_{2} x_{2}+a_{3} x_{3}+a_{4} x_{3}^{2}+a_{5} x_{4}+C_{0} \\
& 0 \leq x_{k} \leq 1 \quad \text { for } k=1,2 \\
& i=8,10,12,14,15,16,17,18
\end{aligned}
$$




$$
j=8,10,12,14,16,18, i+1 \quad \text { for } i<j
$$

但し

$$
\begin{aligned}
& P_{i, j}: \text { 予測修正時間 } i \text { における時間 } j \text { の需要 }[\mathrm{kW}] \\
& a: \text { 各説明変数の係数 } \\
& x_{1}: \text { 正規化された年間 }(\text { 週別 }) \text { 需要パタン } \\
& x_{2}: \text { 正規化された週間 }(\text { 曜日別 }) \text { 需要パタン } \\
& x_{3}: \text { 気温 }\left[{ }^{\circ} \mathrm{C}\right] \\
& x_{4}: \text { 予測修正時間 } i \text { の需要 }[\mathrm{kW}] \\
& C_{0}: \text { モデル式の切片 }
\end{aligned}
$$

制御当日の需要予測のために，前日に翌日の需要曲線を 予測し，当日にその予測カーブを補正する方法を以前の研 究では採用していたが，ここではNAS 電池の放電が始まる 8 時から 2 時間間隔で逐次予測を繰り返す。需要予測の対 象は, 現時点から 2 時間間隔で将来の時点とする。但し, 予 測修正時間の 1 時間後は非常に相関が強いため, 予測需要 点として加える。また, 需要の立ち下がりの予測精度は, 電 池の枯渴に対して影響が大きいため，予測修正時間に 15,17 時を加え，予測修正間隔を 1 時間にすることで，影響を小 さくした。

予測対象日前日から一年前のデータを使用し重回帰モデ ルを作成する。しかし, 休日や講義の行われていない日は, NAS 電池の放電が無く, 最大需要更新の可能性も低いと考 え分析から除外している。需要曲線を求める必要があるの で，重回帰モデルは 8 時，10 時，12 時…と, 予測対象時間 毎に作成する。各説明変数の扱いについて以下に記す。

（1）年間需要パタン一般的に需要家は，年間の需 要変動の傾向を把握できることも多い。実績データからこ のような年間需要パタンを数量化しておくと, 年間の需要 スケジュールの変更が予定される場合には，このパタンを エネルギー管理者が修正することで対応できる。重回帰分 析では説明変数を数量化する必要があるため，休日を除い た週毎のデータで平均化法を行い，年間の最大需要が 1 と なるよう正規化した数量データを説明変数として用いた。 週毎に需要を平均し正規化したものを Fig. 3 に示す（年末 年始除く）。週は年間で 52 週もしくは 53 週あり，年間の 需要傾向を読み取ることができる。

(2) 週間需要パタン 多くの需要家は, 曜日毎に需 要パタンが決まっており，同曜日の需要傾向に変わりが無 い。明星大学の需要も, 曜日毎の週間需要パタンを得るこ とができる。Fig. 4 に最大需要を 1 に正規化した週の需要 パタンを示す。この図から以下のことが読み取れる。

・月曜日は他の平日に比べ，わずかに需要が小さい。

・火曜日から金曜日までの平日は需要変動が小さい。そ のため，曜日の変化によってあまり影響を受けない。

・土曜日の需要は, 平日と比較すると需要が小さい。

(3) 気温平均気温とピーク需要の関係を Fig. 5 に 示す。一般的に重回帰分析は, 線形関係の変数からモデル 式を構築する。しかし，気温と需要の関係は，線形ではな

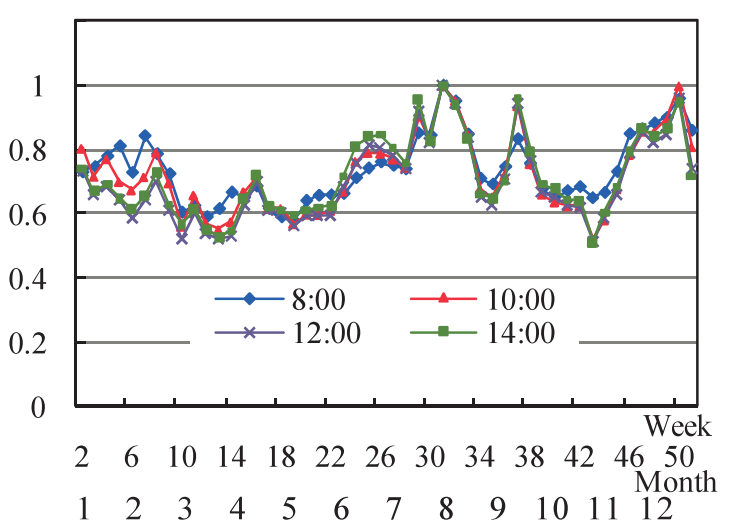

Fig. 3. Normalized load for 53 weeks in a year (2007).

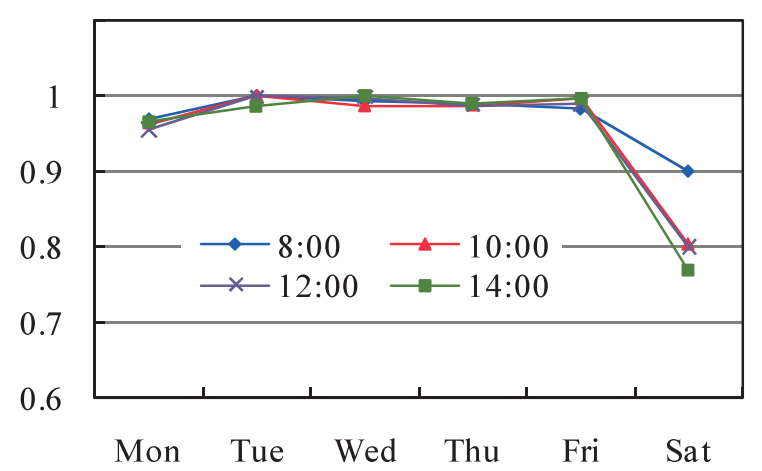

Fig. 4. Normalized load of each day of a week (2007).

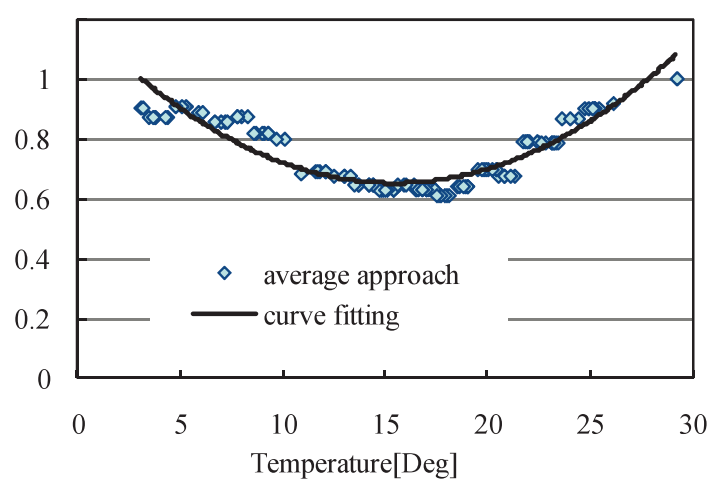

Fig. 5. Characteristic of temperature against peak demand.

く下に凸の曲線であることが知られている。また，猛暑や 極寒時の高需要時には夏・冬季休業が重なり, 簡便な平均 法による数量化では精度が悪くなる。そのため，気温に関 しては，気温と気温の二乗值をそのまま説明変数に使うこ とにした。

$\langle\mathbf{2} \cdot \mathbf{3}\rangle$ 需要曲線の検索 需要予測では最大電力では なく, 需要曲線として求めることが, NAS 電池の適正な運 用制御に必要である。需要曲線を作成するためには, 前項 の重回帰モデルから予測した, 予測対象時間の需要を直線 で結ぶような簡便な手法もあるが，ジグザグしたり常識を 逸脱した曲線が求まる恐れがある。そのため本稿では, 各 季節の需要パタンが含まれるように過去 1 年間の実績曲線 から予測点の近傍を通る曲線を選び出し, 波形を合成する 
Table 2. Demand points to search the past demand curves.

\begin{tabular}{|c|c|c|c|c|c|c|c|c|c|c|c|c|}
\hline 7 & 8 & 9 & 10 & 11 & 12 & 13 & 14 & 15 & 16 & 17 & 18 & 19 \\
\hline 8 & $x$ & 0 & 0 & & 0 & & 0 & & 0 & & 0 & \\
\hline 10 & (0) & & $x$ & 0 & 0 & & 0 & & 0 & & 0 & \\
\hline 12 & (2) & & (0) & & $x$ & 0 & 0 & & 0 & & 0 & \\
\hline 14 & (a) & & (0) & & (0) & & $x$ & 0 & 0 & & 0 & \\
\hline 15 & (0) & & (2) & & (0) & & (0) & $x$ & 0 & & 0 & \\
\hline : 16 & (2) & & (a) & & () & & () & & $x$ & 0 & 0 & \\
\hline 17 & (0) & & (0) & & (0) & & (0) & & (a) & $x$ & 0 & \\
\hline 18 & (0) & & (0) & & () & & (2) & & (2) & & $x$ & 0 \\
\hline
\end{tabular}

(๖):Real demand $\bigcirc$ :Forecasted demand $x:$ Revised forecasting time

手法を採用した。この手法では過去実績デー夕を基にする ため，過去実績から大きく逸脱した曲線を予測せず，大き な予測䛊差の発生を避けることができる。

需要曲線検索には, 実績需要点・予測修正時間の需要を 含む 7 点からの誤差が最も小さい上位 5 日（以下 Top5）の 需要曲線を選出する。その 5 本の需要曲線を単純平均して 予測曲線とする。Table 2 には各予測修正時間に扮いて検索 に使用する需要点を示す。また (2) 式に過去実績と需要点 の誤差式，(3) 式に需要曲線の算定式を示す。

$$
\begin{aligned}
& E r r=\sum_{d=1}^{l}\left(P_{n, T[d]}-P_{m, T[d]}\right)^{2} \ldots \ldots \ldots \ldots \ldots \ldots(2) \\
& P_{\text {avg, } t}=\frac{\left(P_{T o p 1, t}+P_{T o p 2, t}+P_{T o p 3, t}+P_{T o p 4, t}+P_{T o p 5, t}\right)}{5}
\end{aligned}
$$

Err : 䛊差

$T[d](d=1,2, \ldots, l)$ : 予測と実績を含む需要点 $l=$ 7 (時点数)

$P_{n, T[d]}$ : 予測対象日 $n$ における $T[d]$ 時点の需要

$P_{m, T[d]}:$ 過去日 $m$ における $T[d]$ 時点の需要

$P_{a v e, t}: t$ 時における過去実績 $P_{t o p 5}$ を平均した $t$ 時 の予測需要

$t: 1$ 日 24 時間を 30 分間隔で刻んだもの $(t=$ $1,2, \ldots, 48)$

\section{3. 適正運用のための制御手法}

NAS 電池の運転方式にはパタン固定運転と負荷追従運転 がある。負荷追従運転は, 充電した電力を需要の変動に合 わせて放電する運転方式であり，事前想定の難しくなって きた需要の変化に反応して契約電力超過（ピークオーバー） を防止できる。しかし，需要に合わせて放電するために， 適正な制御をしないと放電が必要とされる前に電池残量を 使い切り (電池枯渴)，ピークオーバーに至る恐れがある。 一方, 充電した電力を夜間までに使い切らないと（電池余 剩), 昼夜間の電気料金価格差による運用メリットを生かす ことがでず，設備の有効利用が図れない。
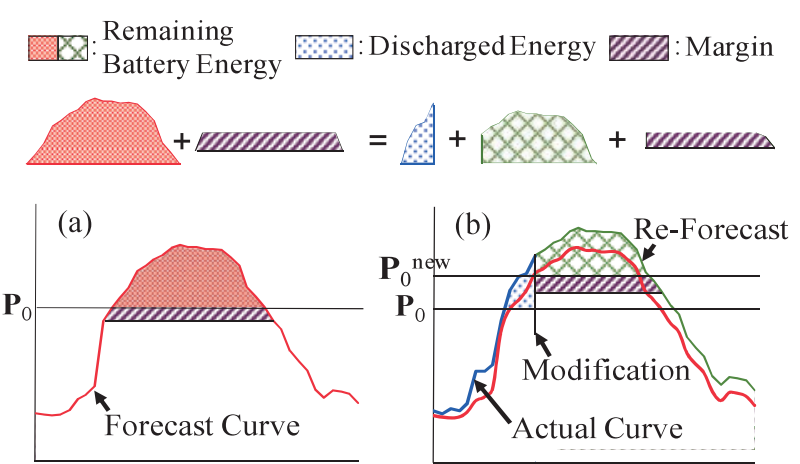

Fig. 6. Modification of the target $\left(\mathrm{P}_{0}\right)$ of receiving power.

NAS 電池の負荷制御の目的関数（評価関数）を一意的に 決めることは難しい。需要家からの要求には以下のような ものがある。

（1）年々の需要増による契約電力増加は避け難いが, 不用意なピークオーバーは発生させたくない。

（2）導入した電池設備の容量を十分に活用して電気料 金の低減に寄与させたい。

（3）様々な料金割引の契約メニューを活用したい。

（4）需要調整に関してNAS 電池も協調させ, 受電電 力はできれば平坦に維持したい。

本章ではこのような要求を列挙順に従って満たすような 制御を目的として, 前章の需要予測曲線を用いて, 電力貯 蔵装置の負荷追従運転を適正に制御する手法を論ずる。

〈3・1 負荷追従運転制御の基本ロジック 予測修正 時間に扮ける負荷追従運転の基本的な制御手順を以下に示 す。この手順は予測誤差を逐次補正しながら，充電されて いる電力を需要曲線の頭頂部に割り当て, 受電電力を平坦 に保つような制御を目指している。

（1）前章の予測手法を用いて，需要曲線を予測する (Fig. 6(a) 中曲線)。

（2）過去波形の和として求めた予測曲線を，予測修正 時間において, 直近の需要実績值と一致させるよう 上下に平行移動させ，予測修正時間以降の予測曲線 とする。

（3）過去の予測対象日（需要予測・運用制御を行った 日）の予測と実績結果から, 確率的に電池枯渴を起こ さないようにマージン (予備量)を計算する (Fig.6(a) 中斜線部)。

（4）修正時間における電池残量からマージンを差し引 く。(運用に用いる電力量 $=$ 放電可能電力量 - マー ジン)

（5）修正時間以降の需要予測曲線の上部に運用に用い る電力量が当てはまるように目標受電電力 $\mathrm{P}_{0}$ (閾値) を計算する (Fig. 6(a))。

（6）需要家の負荷が $\mathrm{P}_{0}$ を超えた時, 超えた需要電力分 を電力貯蔵装置の放電電力で賄う（Fig. 6(b) 点部）。

（7） $\mathrm{P}_{0}$ が過去に記録した最大受電電力を超えた場合, 
最大受電電力を超えた電力を電力貯蔵装置の放電電 力で賄う。

（8）以上の（1)〜（7) を予測修正時間毎に繰返す (Fig. 6(b))。

需要家に扮ける電気料金低減策は, 最大受電電力を抑え ることで契約電力を下げ基本料金削減を図るものと，夜間 充電・昼間放電により従量料金単価の差異を利用した従量 料金削減を図るものがある(6)。一般的には，契約電力抑制 の方が経済的影響は大きいので，こちらを優先（手順 (7) 参照）しながら，過不足無く放電が完了するよう制御する。

〈3・2〉 リスク回避のためのマージン算出方法 負荷 追従制御において, 最も回避しなければならない失敗事例 は, 「目標受電電力 $\mathrm{P}_{0}$ を低く設定して放電を進め, ピークを 迎える時点または需要の立ち下がりが遅れた時点で電池が 枯渴して受電電力が突出し, 契約電力 (これまでの最大受 電電力）を更新すること」である。しかし，これを恐れて放 電を抑制し過ぎると電池残量が翌日に持ち込まれ，従量料 金削減が図れず，設備の利用も非効率になる。そこで，電 池枯渴と電池余剩のリスクを過去実績の統計から確率的に 分析し、リスク回避のために必要なマージンを残すことに した。以下にこのマージンの適正容量の算定法を説明する。

まず，過去の予測と実績結果を統計処理し，各修正時間 以降の予測誤差の平均值 $\mu$, 標準偏差 $\sigma$ を求める。予測曲 線に $\mu$ と $k \sigma$ ( $k$ : 安全係数)を加算した曲線を想定し, 予測 曲線との差を積算したものを Fig. 7 の概念図を示す。ここ で, 例えば $k=2$ とすると $2 \sigma$ すなわち $95.5 \%$ の確率で予 測誤差を吸収するためには斜線部の面積（電力量）をマー ジンとして確保して, 電池枯渴を防ぐ必要がある。逆に予 測に $\mu$ を加え, $k \sigma$ を減じた曲線は, 電池残量が夜間带まで 使われずに余剩してしまう余剩確率曲線を表している。

安全係数 $k$ の選択は需要家の判断に委稀られる。安全係 数を大きくすると, 枯渇による最大受電電力更新の危険は 下がるが, 負荷平準化に使える電力量は減少するので, 受電 電力の抑制効果が減じ，余剩リスクが増加する。この安全 係数の決定はピーク近傍の変動の急峻さや, NAS 電池の設 備容量, 契約電力の裕度などを勘案して決める必要がある。 実務上は電池残量の計測精度に関しても，十分な配慮が

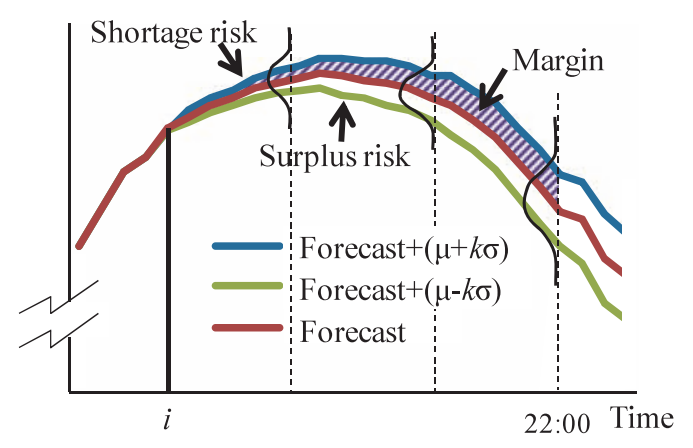

Fig. 7. Calculation of the margin at revised forecasting time $i$.
必要であるが, 自己放電しない NAS 電池では, 充放電電力 の積算值から算定した残量の把握でも大きな問題はない。

\section{4. シミュレーションによる検証}

$\langle 4 \cdot 1\rangle$ 需要予測精度 各修正時刻に扔ける予測曲線 の例を Fig. 8 に示す。Fig. 8(a) から受電電力更新の可能性 がある需要の高い日でも, 精度の良い予測ができることが わかる。一方, Fig. 8(b) では修正時刻 8:00 において, 実績 から大きく外れた予測をしている。しかし，12:00の修正時 刻では実績と良く合った予測に修正していることがわかる。

Fig. 9 に各修正時刻から 20:00 までの絶対值平均誤差分 布を示す。修正時刻 8:00では, 10\%を超える誤差が度々見 られるが, 修正時刻 12:00 の段階ではすべてが7\%以下に 収まっている。12:00 以降の修正時間においても 12:00 と 同様な分布を確認しており, 概ね良好な予測が行えたと言 える。

$\langle\mathbf{4} \cdot \mathbf{2}\rangle \quad$ 負荷追従制御の適応 Fig. 10 に 2008 年の授 業日（151日）に対して負荷追従制御のシミュレーション を行った例を示す。Fig. 10(a)では, 予測精度が良く受電電 力の平準化に成功している。Fig. 10(b) の例では修正時間 8:00，10:00 のように予測誤差が大きく目標受電電力 $\mathrm{P}_{0}$ を 頻繁に修正したが，安定な運転ができている。

負荷追従制御のシミュレーション結果を Table 3 に示す。 これより, パタン固定運転より負荷追従運転の方が, 最大 受電電力を抑えられ, 負荷平準化効果により日負荷率も改 善できることがわかる。しかし, 安全係数 $k$ を大きくし過 ぎるとマージンが大きすぎて，22:00 までに電池残量を使 い切ることができず，余剩する頻度が増えている。そのた

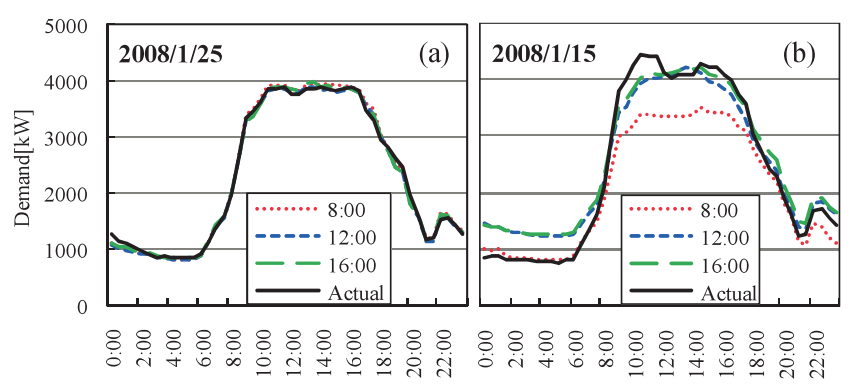

Fig. 8. Forecasted curves at each revised forecasting time.

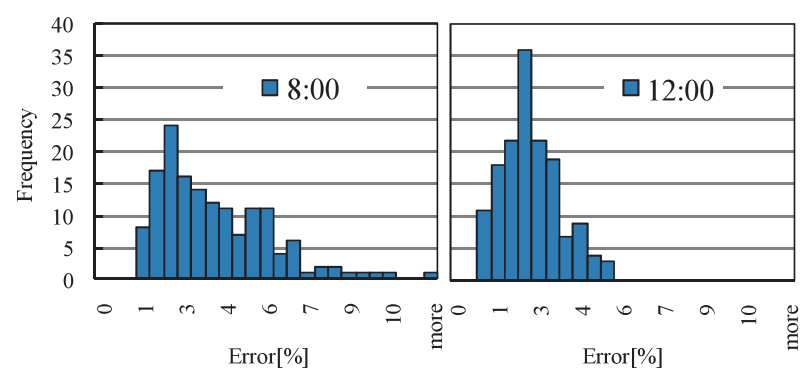

Fig. 9. Error distribution histogram of 151 days (at 8:00, 12:00). 

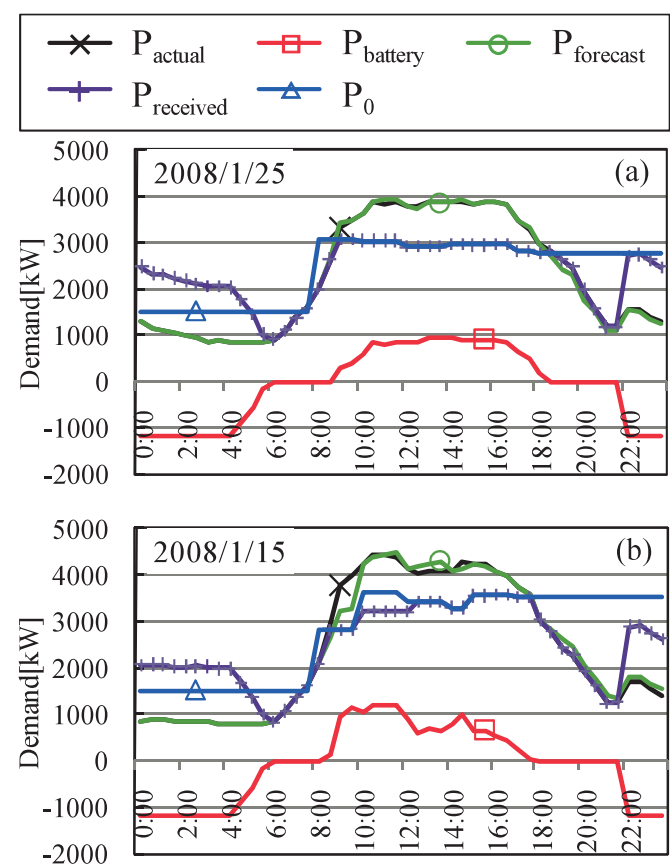

Fig. 10. Load levelling of the load following operation mode.

Table 3. Comparison with fixed pattern operation mode.

\begin{tabular}{|c|r|r|r|}
\hline & $\begin{array}{c}\text { number of } \\
\text { surplus }\end{array}$ & $\begin{array}{c}\text { max } \\
\text { receiving power [kW] }\end{array}$ & $\begin{array}{c}\text { mean daily } \\
\text { load factor [\%] }\end{array}$ \\
\hline Fixed pattern & 0 & 3807 & 70.3 \\
\hline$k=0$ & 0 & 3577 & 74.0 \\
\hline$k=1$ & 0 & 3564 & 73.9 \\
\hline$k=2$ & 6 & 3574 & 73.5 \\
\hline$k=3$ & 42 & 3710 & 72.8 \\
\hline
\end{tabular}

め, 安全係数の設定の際には電池の余剩についても考慮す る必要がある。

なお，最大受電電力更新の可能性は，昼間のみならず夜 間の充電時間带にもあるが，本シミュレーションでは夜間 には負荷追従制御をしなくても最大受電電力を超えずに, 満充電できた。しかし，需要家によっては夜間の運用に関 しても制御が必要になることもあり，今後の課題としたい。

本手法の妥当性を検証するためには，より多くの需要家 データを用いて検証する必要がある。現在商用ビル, ショッ ピングセンター，工場のデータ等を用いて検証中だが，需 要パ夕ンが年々変化する場合や，夕刻以後にピークを迎え， 方形波のようなパタンのショッピングセンターの需要予測 では精度維持が難しい傾向が見られた。

\section{5. あとがき}

需要家における電力貯蔵装置の制御として, 明星大学キャ ンパスに設置されているNAS 電池を題材とした負荷追従 制御手法を提案した。ここでは需要家の需要予測を制御中 に逐次行う手法を用いており，重回帰分析を用いるこの手 法の予測誤差は，ほほ7\%以内で安定している。需要家の
ニーズに合わせた実用的な負荷追従運転手法は, 最大受電 電力の更新を抑制しながら定格容量全量の充放電を目標と しており，自らの手法の予測誤差を統計分析して求めた標 準偏差を活用してマージンを準備することで電池枯渴リス クを回避している。実績データを用いたシミュレーション ではパタン固定運転に比べて良好な結果が得られた。

提案手法は需要家の過去実績負荷と気温のデー夕のみ使 用しており，他需要家に広く適応できる汎用性がある。今 後は多くの需要家データでも検証し，あわせて夜間の負荷 追従制御（充電制御）の付加を検討していきたい。

(平成 22 年 2 月 1 日受付，平成 22 年 4 月 17 日再受付)

\section{文献}

(1) T. Tsuji, R. Hara, and T. Oyama: "Distributed Generations and Demand and Supply Control Technologies", IEEJ Trans. PE, Vol.129, No.9, pp.10661069 (2009-9) (in Japanese)

过 隆男 · 原 亮一. 大山 力:「分散型電源と需給運用制御技術」, 電学論 B, 129, 9, pp.1066-1069 (2009-9)

(2) N. Amjady: "Short-Term Hourly Load Forecasting Using Time-Series Modeling with Peak Load Estimation Capability", IEEE Trans. Power Syst., Issue 3, Vol.16, pp.498-505 (2001-8)

(3) J.W. Taylor and P.E. McSharry: "Short-Term Load Foresting Method: An Evaluation Based on European Data", IEEE Trans. Power Syst., Issue 4, Vol.22, pp.2213-2219 (2007-11)

（4） NEDO 技術開発機構：「新エネルギー等地域集中実証研究/八戸市水 の流れを電気で返すプロジェクト」，「系統連係技術開発及び開発事 業」成果報告会資料

(5) J. Shimizukawa, C.-Y. Chen, K. Iba, Y. Hida, R. Yokoyama, K. Tanaka, and K. Yabe: "Multi-Regression Model for Peak Load Forecast in Demand Side like University Campus", ICEE (2009)

(6) J. Koda, K. Yabe, T. Amemiya, K. Tanaka, and K. Iba: "Discharge Operation of On-site NAS Batteries under Load Forecast Uncertainties", Proc. of the $19^{\text {th }}$ Annual Conference of Power \& Energy Society, IEE of Japan, 195, pp.17-7-17-8 (2008) (in Japanese)

香田 潤 - 矢部邦明 · 雨宮环磨 - 田中晃司 · 伊庭健二 : 「予測需要の 不確実性を考慮した需要家設置 NAS 電池の最適放電運用」, 平成 20 年電気学会電力・エネルギー部門大会, 195, pp.17-7-17-8 (2008)

樋 田 祐 輔 (学生員) 1986 年 2 月 9 日生。 2008 年 3 月明星

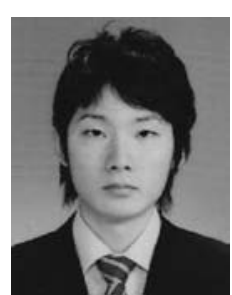
大学理工学部電気工学科卒業。2010 年 3 月早稲 田大学大学院環境・エネルギー研究科修士課程修 了, 同年 4 月同大学院博士課程入学, 現在に至る。 主として電力貯蔵用蓄電池の運用制御に関する研 究に従事。IEEE 学生会員。

横 山 隆 - (上級会員) 1944 年 8 月 25 日生。 1968 年 3 月

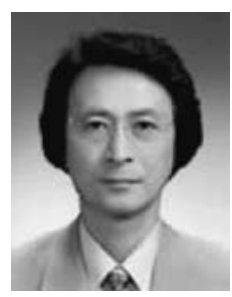
早稲田大学理工学部電気工学科卒業。同大学院に 扔て 1970 年修士, 1974 年博士課程修了, 工学 博士。三菱総合研究所, 東京都立大学を経て 2007 年より早稲田大学大学院環境・エネルギー研究科 教授。電力システムの計画・運用・制御に関する 教育研究に従事。電気設備学会, CIGRE 会員, 経 済産業省の各種委員会委員長を歴任, コンソーシ アム電力技術懇談会副会長，IEEE Fellow。 


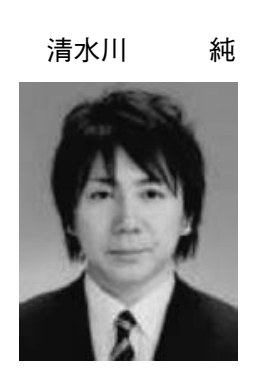

田中晃司

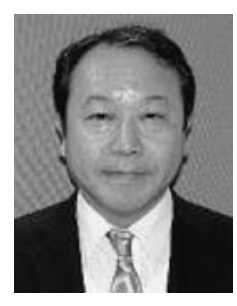

（正員） 1957 年 4 月 23 日生。1981 年 3 月早稲田 大学理工学部電気工学科卒業。同年 4 月より, 東 京電力 (株) 入社。現在, 同社法人営業部兼技術部 にて電力設備ソリューション技術を担当。NAS 電 池等の蓄電池活用・エンジニアリング業務に従事。

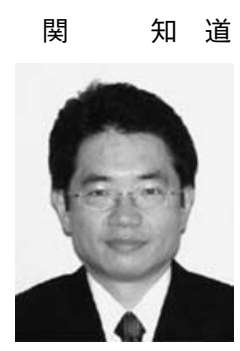

(正員) 1964 年生。1986 年 3 月横浜国立大学工 学部電気工学科卒業。同年 4 月より, 東京電力 (株) 入社。現在, 同社技術開発研究所エネルギー 経済グループマネージャーとして, リスク評価等 の研究開発に従事。

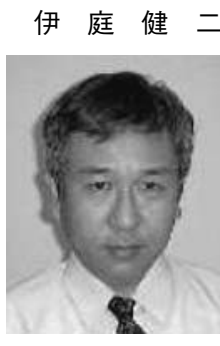

早稲田大学理工学部電気工学科卒業。1980 年同大 学院修士課程修了。同年, 三菱電機 (株) 入社後 電力系統技術の研究開発に従事。特に系統計画, 電圧安定性, 大電力貯蔵技術に従事。2003 年より 明星大学理工学部電気電子システム工学科教授。 IEEE Fellow。 